Sains Malaysiana 49(9)(2020): 2221-2229

http://dx.doi.org/10.17576/jsm-2020-4909-19

\title{
Functional Properties of Tilapia's Fish Scale Gelatin Film: Effects of Different Type of Plasticizers
}

(Ciri Kefungsian Filem Gelatin Sisik Ikan Tilapia: Kesan Jenis Pemplastik yang Berbeza)

\author{
Nazatul Shima Azmi, Roseliza Kadir Basha*, Nurfatin Nabila Tajul Arifin, Siti Hajar Othman \& \\ MOHD AFANDI P. MOHAMMED
}

\begin{abstract}
The aim of this study was to investigate the functional properties of Tilapia's fish scale gelatin films with various type of plasticizers. Gelatin film solutions using solution casting method with different type of plasticizers; glycerol, sorbitol, glycerol: sorbitol (80:20), and diethylene glycol with concentration of $30 \%$ were stirred at $60{ }^{\circ} \mathrm{C}$ for one hour and dried at room temperature for 2 days. The determination of film characterizations was included thermal (thermogravimetric analysis (TGA) and differential scanning calorimetry (DSC)), mechanical testing using the Texture Analyzer and chemical properties (Fourier transform infrared spectroscopy (FTIR)). Essentially, all plasticizers show an improvement by able to plasticizing with increasing of elongation at break in between 14 and $50 \%$ compared to the gelatin film without plasticizer. Meanwhile, the tensile strength of plasticized gelatin films decreased drastically compared to the unplasticized gelatin film. From the result obtained in TGA analysis, film with sorbitol and dietheylene glycol demonstrated low resistance toward high temperature compared to film with glycerol and glycerol:sorbitol gelatin film. In addition, all the gelatin film with different plasticizers show the value of $\mathrm{T}_{\mathrm{g}}$ around $60-70.85{ }^{\circ} \mathrm{C}$ except for sorbitol with $\mathrm{T}_{\mathrm{g}} 79.98^{\circ} \mathrm{C}$ due to strong intermolecular chain interaction between the sorbitol and gelatin. FTIR spectrum analysis demonstrated that only gelatin film with glycerol does not have any amide group that related to stretching vibration of carbonyl group along the polypeptide backbone of the plasticized film which later give highest tensile strength. Hence, notable differences of functional properties were found with four different type of plasticizers used in the gelatin film, especially in term of temperature resistance and mechanical properties.
\end{abstract}

Keywords: Functional properties; plasticizer; tilapia's fish scale gelatin

\section{ABSTRAK}

Tujuan kajian ini adalah untuk mengkaji ciri kefungsian filem gelatin sisik ikan Tilapia dengan pelbagai jenis pemplastik. Larutan filem gelatin yang dihasilkan menggunakan kaedah acuan larutan dengan pelbagai jenis pemplastik; gliserol, sorbitol, gliserol:sorbitol (80:20) dan dietilena glikol dengan kepekatan 30\% diaduk pada 60 ${ }^{\circ} \mathrm{C}$ selama satu jam dan dikeringkan pada suhu bilik selama 2 hari. Beberapa penentuan pencirian filem ditentukan termasuk termal (analisis termogravimetri (TGA) dan kalorimetri pengimbas pembezaan (DSC)), ujian mekanikal menggunakan penganalisis tekstur dan sifat kimia (spektroskopi inframerah transformasi Fourier (FTIR)). Pada dasarnya, semua pemplastik menunjukkan peningkatan pembaikan pada pemanjangan ketika putus sebanyak 14 hingga $50 \%$ berbanding dengan filem gelatin tanpa pemplastik. Sementara itu, kekuatan tegangan filem gelatin dengan pemplastik menurun secara mendadak berbanding dengan filem gelatin tanpa pemplastik. Daripada hasil yang diperoleh dalam analisis TGA, filem mengandungi sorbitol dan dietilena glikol menunjukkan rintangan rendah terhadap suhu tinggi jika dibandingkan dengan gelatin filem yang mengandungi gliserol dan gliserol:sorbitol. Di samping itu, semua filem gelatin berbeza pemplastik menunjukkan nilai $\mathrm{T}_{\mathrm{g}}$ antara $60-70.85{ }^{\circ} \mathrm{C}$ kecuali sorbitol dengan $\mathrm{T}_{\mathrm{g}} 79.98$ ${ }^{\circ} \mathrm{C}$ kerana interaksi antara rantaian intermolekul yang kuat antara sorbitol dan gelatin. Analisis spektrum FTIR menunjukkan bahawa hanya filem gelatin dengan gliserol tidak mempunyai kumpulan amida yang berkaitan dengan peregangan getaran kumpulan karbonil di sepanjang tulang belakang polipeptida filem plastik yang kemudiannya memberikan kekuatan tegangan tertinggi. Oleh itu, perbezaan sifat kefungsian yang ketara didapati dengan empat jenis pemplastik yang digunakan dalam filem gelatin, terutamanya dalam rintangan suhu dan sifat mekanikal.

Kata kunci: Ciri kefungsian; gelatin sisik ikan tilapia; pemplastik 


\section{INTRODUCTION}

The development of biodegradable material has been used extremely and effectively as an alternative to petroleum-based packaging material, which are nonbiodegradable and negatively impact to the environment. Thus, bio-polymer based packaging material from naturally renewable origin has become a current trend in research area. Moreover, biodegradable materials guarantee eco-friendly, non-toxic, environmental stability, and have many desirable physico-chemical characteristics over synthetic ones. Biodegradable films are made from different polymer types, which include polysaccharides, proteins, and lipids or combinations of these materials (Tongnuanchan et al. 2012). Based on all these materials, protein has been used extensively and have impressive potential for biodegradable film application due to the abundance and good film forming abilities (Nor et al. 2017). Proteins are heteropolymers containing more than 100 amino acids residue and made from 20 proteinogenic amino acids that are joined together by amide bonds, polypeptides (Nur Hanani et al. 2014). Moreover, the protein-based films have excellent oxygen, carbon dioxide and volatile compounds barrier properties under low relative humidity conditions (Limpan et al. 2010; Tongnuanchan et al. 2012).

Gelatin is animal protein which can be derived from the partial hydrolysis of native collagens which abundantly' can be found in in skins, bones, connective tissue, and scale (Chuaynukul et al. 2017). Gelatin based film made up from bovine and porcine skins have present to exhibit much stronger mechanical properties than others raw material due to the high concentration of proline hydroproline (Yi et al. 2006). Unfortunately, due to the religious matter in consumptions of this mammalian and health concern about the spread disease to human, biodegradable film from fish gelatin have increase the attention (Chuaynukul et al. 2017; Weng et al. 2014). Hence, to overcome this issue, the gelatin extracted from the fish scale which are rich in collagen have been used widely in encapsulation and edible film formation. It has also been reported that the fish gelatin exhibit excellent film-forming property among the biopolymers (Mohammad et al. 2014; Weng \& Wu 2015). In fact, gelatin films exhibited some good advantage as film properties, unfortunately fish gelatin films showed poor mechanical properties compared to mammalian gelatin films and some synthetic films which result on the restriction of their wide application as packaging materials due to the strong polymer cohesive energy density (Nor et al. 2017; Weng \& Wu 2015). Hence, to overcome the problems, the use of plasticizers helped to decrease this inherent brittleness by reducing the intermolecular forces that increase polymeric chain elasticity which then improves the flexibility (Thomazine et al. 2005). The process of curing the brittleness of gelatin is known as the plasticization of gelatin. Among all the possibilities of additives that can be used in protein based film is glycerol (Limpisophon et al. 2009; Tongnuanchan et al. 2012).

To date, there is less research done pertaining to the influence of various plasticizers on the Tilapia's fish scale gelatin film. Hence, the aim of this current investigation was to determine the effect of different plasticizers type (glycerol, sorbitol, glycerol:sorbitol and diethylene glycol) on the functional properties of Tilapia's fish scale gelatin film.

\section{MATERIALS AND METHODS}

\section{EXTRACTION OF GELATIN FROM TILAPIA FISH SCALE}

Tilapia (Tilapia zilli) fish scale was obtained from a local wet market at Jerantut, Pahang, Malaysia. For the storage purpose, the fish scale was kept frozen in refrigerator at $-20^{\circ} \mathrm{C}$. Gelatin was extracted from Tilapia's fish scale according to the procedure of Limpisophon et al. (2009) and Weng and Wu (2015) with slight modification. First, the scales were washed with tap water to remove the dirt. Then, the scales were soaked in a solution containing $0.05 \mathrm{~N}$ sodium hydroxide $(\mathrm{NaOH})$ and $25 \%$ of methanol with a scale/solution ratio of $1: 4(\mathrm{w} / \mathrm{v})$ at $10{ }^{\circ} \mathrm{C}$ for $24 \mathrm{~h}$. Alkaline treated scales were washed with the tap water to achieve the neutral $\mathrm{pH}$. The scales were then soaked in 5 volumes of $0.05 \mathrm{~N} \mathrm{HCl}$ for $2 \mathrm{~h}$ at room temperature. After that, the swollen scales were washed again with the tap water to achieve the neutral $\mathrm{pH}$. After the pretreatment, the swollen scales were soaked in distilled water at $80{ }^{\circ} \mathrm{C}$ for $1 \mathrm{~h}$ to extract the gelatin. The mixture was centrifuged (Universal 320, Hettich GmbH \& Co. Canada) at 15,000 $\times \mathrm{g}$ for $30 \mathrm{~min}$. The supernatant of gelatin extract was freeze-dried and the was stored at $-20^{\circ} \mathrm{C}$ until further used.

\section{PREPARATION OF GELATIN FILMS}

The gelatin films were develop using the same protocol for solution casting method as in González et al. (2016) with some modification. The film forming solution was prepared by dissolved $2 \%(\mathrm{w} / \mathrm{v})$ of the freeze-dried gelatin with $30 \%$ (w/w of the gelatin) of plasticizers in the $60{ }^{\circ} \mathrm{C}$ distilled water for $30 \mathrm{~min}$ with continuous stirring. Glycerol, sorbitol or their 80:20 combination glycerol: sorbitol ratio, and diethylene glycol were used as plasticizers to investigate the effect of each individual plasticizers on the gelatin-based films. Then, the solution underwent sonication for $10 \mathrm{~min}$ (Chang et al. 2010) to remove the air bubble. Then, the film forming solution was casted into $14 \mathrm{~cm}$ internal diameter petri dishes resting on a levelled surface for casting and were dried at room temperature for $24 \mathrm{~h}$. After completely dried, the film was carefully peel off. The film was stored in the seal plastic film at $57 \%$ of humidity (Xu et al. 2005). 


\section{CHARACTERIZATION OF THE FILMS THERMO-GRAVIMETRIC ANALYSIS (TGA)}

Thermo-gravimetric tests were performed using Mettler Toledo thermal analyzer (TA Instruments, New Castle, PA, USA). The tests were carried out at temperature range from 25 to $800{ }^{\circ} \mathrm{C}$ with a heating rate of $10{ }^{\circ} \mathrm{C} \mathrm{min}^{-1}$ under nitrogen gas. Film sample of 5 to $15 \mathrm{mg}$ was placed. The onset decomposition temperature and weight loss profiles were obtained.

\section{DIFFERENTIAL SCANNING CALORIMETRY (DSC)}

Differential scanning calorimetry (Universal V3-9A TA Instrument, New Castle, PA, USA) equipment was used to determine the glass transition temperature of different type of plasticized films. The calibration of the equipment was conducted using indium as standard. For differential scanning calorimetry (DSC) analyses, $5 \mathrm{mg}$ of film samples were weighted and placed in an aluminum sample pan which was immediately sealed. An empty sample pan was used as reference. Film samples were heated from 30 to $195^{\circ} \mathrm{C}$ at a rate of $10^{\circ} \mathrm{C} \mathrm{min}{ }^{-1}$. Nitrogen gas was used to flush the DSC cell at a flowrate of $50 \mathrm{~mL}$ $\mathrm{min}^{-1}$ to maintain an inert environment. The transition temperatures were determined from the thermogram results. The weight loss as function of temperature was depicted as thermal-gravimetric analysis (TGA) curve.

\section{MECHANICAL PROPERTIES}

The mechanical properties were analyzed using Texture Analyzer with a load cell of $5 \mathrm{kN}$ followed to ASTM
D882-02 (2002). Film sample strips, using a size of 100 $\times 15 \mathrm{~mm}$, were cut from each kind of composite films. Before testing, the thickness of the sample was measured using a Digital Vernier Caliper (Model MIT-500-19620, Japan) at ten arbitrary points of the film. Then, the averages of these values were used to calculate the crosssectional area of each sample. The end of each specimen was mounted using a utility tape to prevent cracking and slippage of films during testing. Force $(\mathrm{N})$ and deformation $(\mathrm{mm})$ were recorded with cross-sectional test specimens.

\section{FOURIER-TRANSFORM INFRARED SPECTROSCOPY (FTIR)}

FTIR spectra were recorded on Thermonicolet (Model Nicolet 6700, United State) spectrometer and transmission spectra were obtained by forming thin transparent potassium bromide (KBr) pellets (Saikia et al. 2010).

\section{RESULTS AND DISCUSSION}

THERMO-GRAVIMETRIC (TGA) ANALYSIS

TGA is used to analyse the thermal stability and decomposition behaviour of the polymer sample where the sample is being heated to high temperature in a controlled environment. Table 1 shows the weight losses during heating described it three thermal degradation stages.

TABLE 1. Thermal degradation temperatures $\left(\mathrm{T}_{\mathrm{d}},{ }^{\circ} \mathrm{C}\right)$ and weight loss $\left(\Delta_{\mathrm{w}}, \%\right)$ of Tilapis's fish scale gelatin film incorporated with different plasticizers

\begin{tabular}{lcccccc}
\hline \multicolumn{1}{l}{ Plasticizers } & \multicolumn{3}{c}{$\Delta_{1}$} & \multicolumn{3}{c}{$\Delta_{3}$} \\
\cline { 2 - 6 } & \multicolumn{1}{c}{$\mathrm{T}_{\mathrm{d} 1 \text {, onset }}$} & $\Delta_{\mathrm{w} 1}$ & $\mathrm{~T}_{\mathrm{d} 2 \text {, onset }}$ & $\Delta_{\mathrm{w} 2}$ & $\mathrm{~T}_{\mathrm{d} 3 \text {, onset }}$ & $\Delta_{\mathrm{w}, 3}$ \\
\hline Glycerol & 140.33 & 6.58 & 276.56 & 20.31 & 488.40 & 48.69 \\
Sorbitol & 139.16 & 8.08 & 310.50 & 38.97 & 535.00 & 32.18 \\
Glycerol:sorbitol & 142.83 & 7.63 & 310.50 & 40.18 & 520.50 & 32.68 \\
Diethylene glycol & 140.67 & 9.80 & 283.83 & 27.50 & 503.45 & 45.06
\end{tabular}

The initial stage of thermal degradation is due to the moisture loss of the dehydration on the loosely bound water and/or the evaporation of volatile components in the films that occurred at temperature less than $150{ }^{\circ} \mathrm{C}$
(Tongnuanchan et al. 2014). It can be observed from Table 1 , gelatin film with diethylene glycol had higher weight loss than others. This might be associated with the high amount of water in film incorporated with this type of 
plasticizer and ascribed to more amount of hydrophilic gelatin components in the films which caused by the less hygroscopic of diethylene glycol (Tongnuanchan et al. 2013). The second stage of weight loss $\left(\Delta_{\mathrm{w} 2}=\right.$ $20.31-40.185)$ that occurred at the thermal degradation temperature between 270 and $311{ }^{\circ} \mathrm{C}$ was more likely due to the degradation of plasticizers compound as well as lower molecular weight of protein fractions or the structure of the bound water in the film network (Hoque et al. 2011). Next, the third stage of thermal degradation behaviour is associated with the degradation of the larger size or highly associated protein fraction (Tongnuanchan et al. 2014). For the third stage of weight loss, $\Delta_{\mathrm{w}, 3}$ of $32 \%$ of 520.50 to $535^{\circ} \mathrm{C}$ were observed for gelatin film plasticized with sorbitol and glycerol:sorbitol which is highest in thermal degradation temperature and lower weight loss in compared to others. The higher thermal stability and lower weight loss of the film plasticized with sorbitol was plausibly associated with strong hydrogen bond formation with the inter/intra-molecular protein interaction in the film network. Generally, films incorporated with plasticizers had lower thermal stability in compared to the unplasticized film was in agreement with the weaker film networks as indicated by the lowered tensile strength (Tongnuanchan et al. 2014, 2012). Thus, it can be concluded that plasticizers had marked impact on thermal stability on gelatin.

\section{DIFFERENTIAL SCANNING CALORIMETRY (DSC)}

The glass transition temperature $\left(T_{g}\right)$ for polymers is an essential parameter in many side view of applications, which affects the thermos-rheological behaviour (Backfolk et al. 2007). $T_{g}$ in definition related to the molecular segmental of disordered (amorphous) structure (Jongjareonrak et al. 2006; Tongnuanchan et al. 2014). In addition, it is a very important parameter which depends on molecular structure and interaction as well as chain stiffness which serves to explain the physical and chemical behaviour of material system. DSC thermograms for the $T_{g}$ results of each gelatin film incorporated with different $\stackrel{g}{\text { plasticizers }}$ is shown in Table 2.

TABLE 2. Effects of type of plasticizers on $T_{g}$ of Tilapia's fish sale gelatin film

\begin{tabular}{cc}
\hline Type of plasticizers & $T_{g}\left({ }^{\circ} \mathrm{C}\right)$ \\
\hline Glycerol & 61.64 \\
Sorbitol & 79.98 \\
Glycerol:Sorbitol & 70.85 \\
Diethylene glycol & 66.76 \\
\hline
\end{tabular}

From the result in Table 2, gelatin film plasticized with sorbitol obtained the highest $T_{g}, 79.98^{\circ} \mathrm{C}$ compared to others samples. This observation corresponded with its low moisture content as previously reported by Sanyang et al. (2015). This is because sorbitol has low moisture content which will forms strong interaction with the intermolecular chain of the gelatin later resemblance with glucose units, thus, reducing the possibility of plasticizer-water molecule interactions to occur. Moreover, this strong interaction of molecular structure between the sorbitol and gelatin molecules also have an impacts on the ductility of the film, thus, reflect back to its bonding mechanisms, the higher the bond attraction, the higher the glass temperature.
As for the glycerol-plasticized film, the $T_{g}$ value obtained was the lowest compared to others which is 61.64 ${ }^{\circ} \mathrm{C}$. The additional of glycerol in the gelatin film will creates the hydrophilic hydroxyl groups as active site which will attract the water molecules (Nor et al. 2017; Sanyang et al. 2015). This is due to the hygroscopic characteristics of glycerol. It tends to easily retain the water into the gelatin matrix film. Hence, with high attraction of water molecules retain in the film matrix and considered as a polymer inter-chain mobility enhancer which later will lower the $T_{g}$ value. Moreover, it can be related with the mechanical properties of glycerol plasticized gelatin film which the tensile strength was reduced but increasing in EAB with the lower $T_{g}$. 
Interestingly, the $T_{g,}\left(70.85{ }^{\circ} \mathrm{C}\right)$ for the gelatin film plasticized with the combination of glycerol:sorbitol $(80: 20)$ was obtained intermediately in value between the $\mathrm{T}_{\mathrm{g}}$ for gelatin film incorporated with glycerol (61.64 $\left.{ }^{\circ} \mathrm{C}\right)$ and sorbitol $\left(79.98{ }^{\circ} \mathrm{C}\right)$ which gives the same result pattern in mechanical analysis. This phenomenon can be explained based on the moisture content (Sanyang et al. 2015). As reported by Sanyang et al. (2016), glycerol: sorbitol plasticized film obtained high moisture content followed by glycerol and sorbitol plasticized film which then lowered the $T_{g}$ value. Both glycerol and sorbitol in the film will acts differently which glycerol is water-holding agent and sorbitol entertains less interactions with the water molecules (Sanyang et al. 2016). With these two different distinct characteristics of plasticizers, the glycerol will try to retain the water in the matrix with the strong affinity of hydroxyl groups with water molecules and sorbitol will less interact with water due to high molecular structure resemblance to the sorbitol.

\section{MECHANICAL PROPERTIES}

The effect of different plasticizer on the tensile strength of the Tilapia's scale gelatin film is shown in Figure 1.
From Figure 1, it can be seen that the tensile strength was reduced significantly with the additional of plasticizer from 69.04 MPa for the control film without plasticizer to 20.51, 12.64, 13.84, and 11.28 MPa for glycerol, sorbitol, glycerol: sorbitol, and diethylene glycol plasticized film, respectively. Generally, it is due to the plasticizer molecules bind with the water molecules and shield the active centres along the protein chains (in between the amino acids side chains) which then increasing the intermolecular distances (Shaw et al. 2002; Siew et al. 1999).

For the control film (unplasticized film) has the highest tensile strength which the mechanical behaviour was typically brittle and rigid. This is due to the higher interactions and proximity between proteins chain without existence of any plasticizer (Nor et al. 2017). This phenomenon was in agreement with Nor et al. (2017) and Yang and Paulson (2000) which stated that films without plasticizer are particularly brittle and shattered when handle. Moreover, the availability of plasticizer will develop polymer-plasticizer hydrogen bonds that replace polymer-polymer interactions due to the polar groups along the plasticizer's chain.

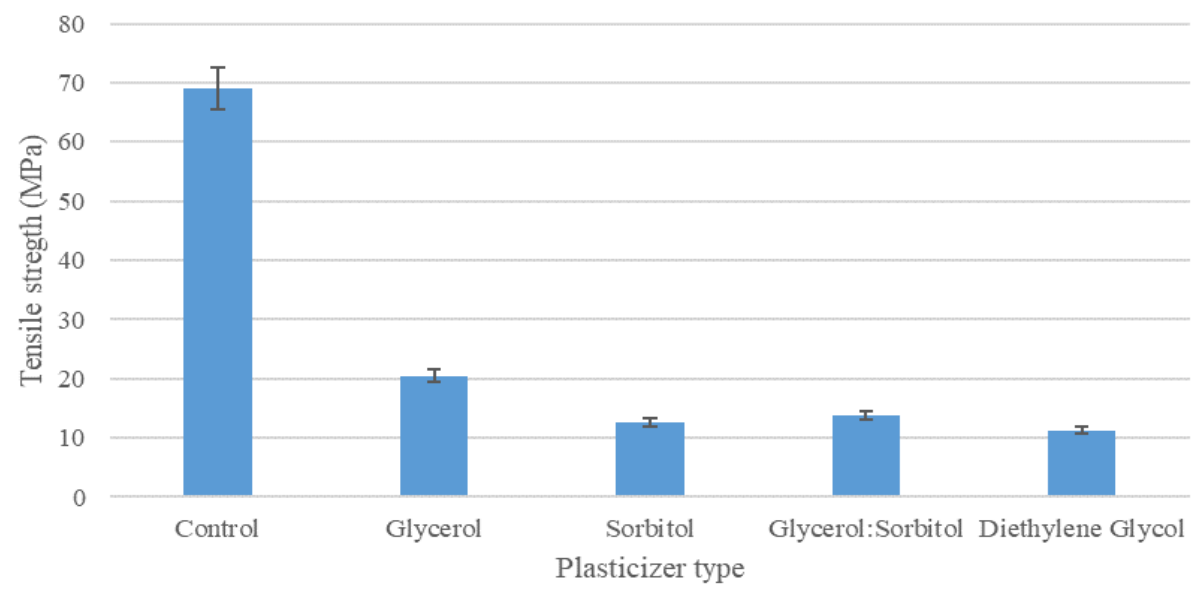

FIGURE 1. Effect of plasticizer type on the tensile strength of Tilapia's fish scale gelatin film

By comparing the plasticized film, the highest tensile strength was obtained at 20.51 MPa with the incorporation of glycerol into film. This is because the additional of the glycerol made the film more ductile in which the glycerol takes the places in between the protein molecules and interferes with the inter-molecules forces and leads to the formation of polymer-plasticizer interactions to the detriment of polymer-polymer interactions. Interestingly, the glycerol:sorbitol plasticized gelatin film, obtained the tensile strength value of $13.84 \mathrm{MPa}$ which is in between the tensile strength of glycerol $20.51 \mathrm{MPa}$ and sorbitol $12.64 \mathrm{MPa}$, respectively. Therefore, the resulting films improve the lower tensile strength of the sorbitol plasticized film and compromise the high tensile strength of glycerol plasticized film. This result is also implied with the $T$ values where the values is in between glycerol and sorbitol plasticized gelatin film. 
Overall, the functionality of the plasticizer incorporated into the gelatin film despite of the type able to reduce the formation of junctions between the adjacent chains in a biopolymer increase the film's mobility and flexibility. The existence of the plasticizer which inserted into the polymer chains, producing the cross-linker effect that reduced the free volume and the segmental mobility of the polymer (Nor et al. 2017).
The effect of the plasticizers on the elongation of Tilapia's fish scale with the elongation of $49-80 \%$ exhibited an inverse trend to the TS as shown in Figure 2. As anticipated, the incorporation of plasticizers into the gelatin film will increase the film elongation as the plasticizer will decrease the intermolecular bonds between protein-protein of the starch matrix and thus substitute with the hydrogen bonds formed between

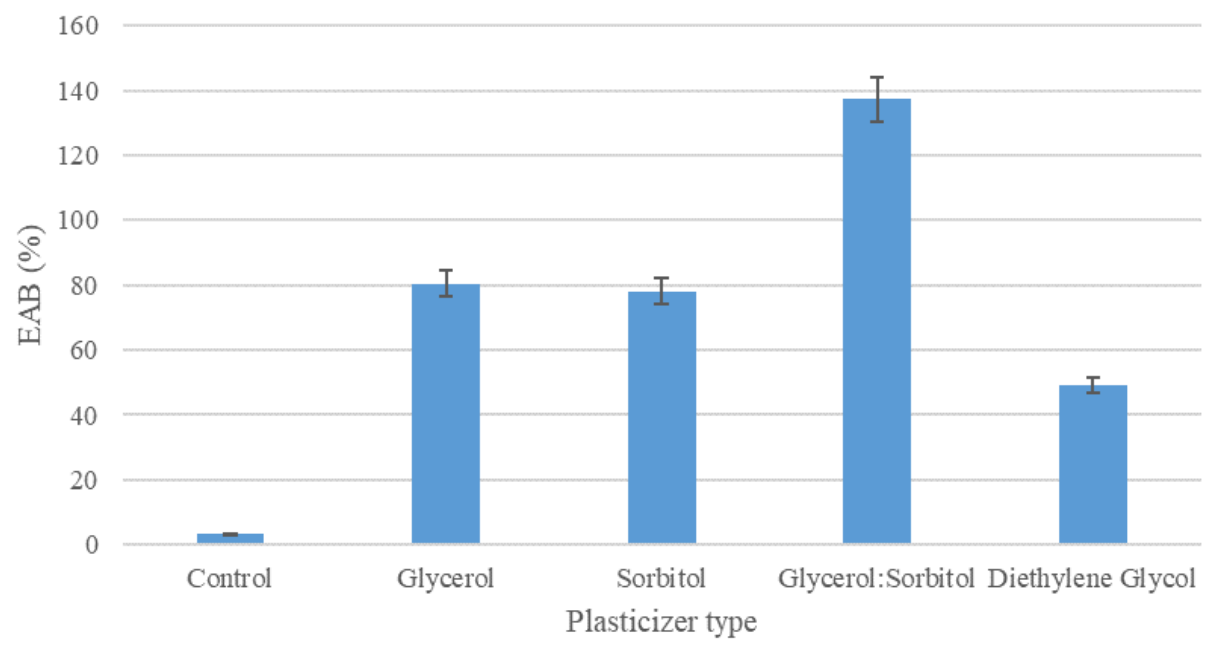

FIGURE 2. Effect of plasticizer type on the EAB of Tilapia's fish scale gelatin film

protein-plasticizer molecules. This interruption and reconstruction of the protein chains will reduce the rigidity and increase the flexibility of the films with more chain mobility (Muhammed et al. 2015). The highest $\mathrm{EAB}$ for the gelatin film was obtained by using combination of glycerol: sorbitol plasticizer with $137.3 \%$ compared to other plasticized films. This is might be due to the combining these two increase the molecular weight of the plasticizers contributes in higher number of molecular chains, thus, the chains will form entanglement among each other and increase the chain mobility.

The stress-strain curves in Figure 3 clearly showed the decreased of the tensile strength and increase in flexibility as plasticizer is incorporated into the gelatin

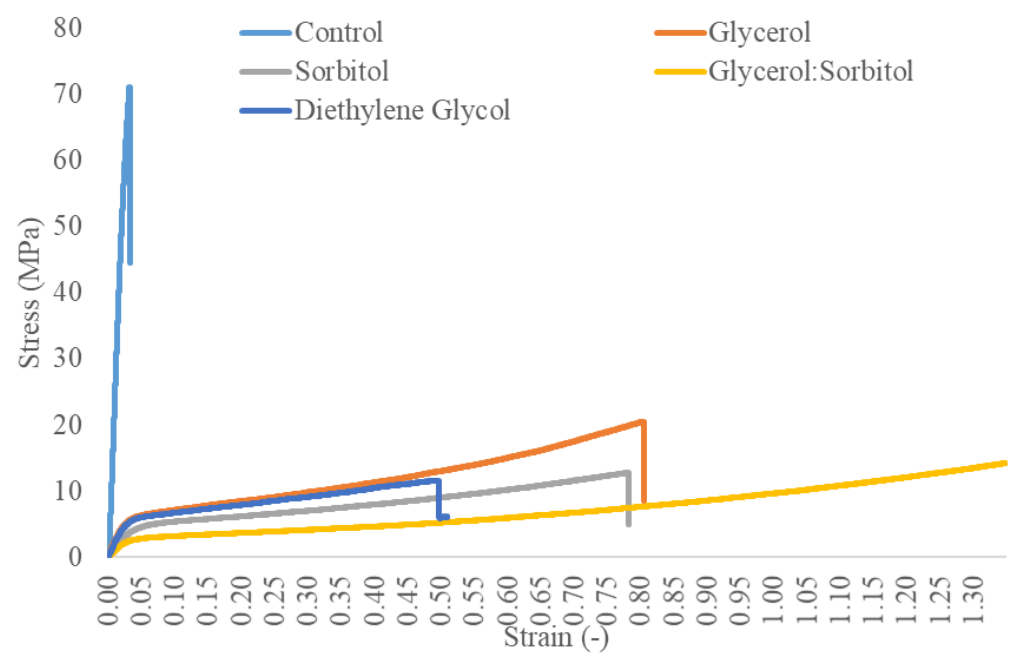

FIGURE 3. Stress-strain curve graph for different plasticized films 
film. As can be seen from Figure 3, the control film (unplasticized film) broke rapidly after yielding. As for diethylene glycol plasticized gelatin film, the stressstrain mechanism showed that it broke more fastest compared to other plasticized film. This is due to the shortest chain length with the lowest hydroxyl group $(-\mathrm{OH})$, hence provide less protein-plasticizers interchain bonding to entangle and can be break easily at low forces applied (Siew et al. 1999).

As expected, the combination of glycerol and sorbitol plasticizers in the gelatin film exhibited superior flexibility and approaching the fracture in a slower and smoother rate compared to the glycerol plasticized film and sorbitol plasticized film. It can be stated that the fracture mechanism alters from swift fracture at low strains to elastoplastic at higher strains (Muhammed et al. 2015).

\section{FTIR ANALYSIS}

The IR spectra of unplasticized and plasticized of Talipia's fish scale gelatin films are presented in Figure 4. Several characteristics can be observed and depicted by four individual peaks marked by Amide I, Amide II, Amide III, Amide A, and aliphatic alcohol.

The Amide band I band spectrum is very sensitive and normally used to study secondary protein makeup. Spectral peaks between 1643 - $1649.03 \mathrm{~cm}^{-1}$ were presented for Amide I for all the samples which indicating for stretching vibrations from $\mathrm{C}=\mathrm{O}$ bands along the polypeptide backbone of the films. Moreover, the Amide I band which frequently occurs at $1600-1700$ $\mathrm{cm}^{-1}$ is mainly associated with $\mathrm{C}=\mathrm{O}$ starching vibrations (70-85\%) and C-N groups (10-20\%) where the exact positions of the band is determined by the backbone's conformation and hydrogen bonding pattern (Nor et al. 2017). This attributed to unordered and $\alpha$-helix structures. On the other hand, Amide II can be seen as narrow absorption bands visible at $1549.4-1551.51 \mathrm{~cm}^{-1}$ for all the gelatin film samples are attributed to $\mathrm{N}-\mathrm{H}$ bending and $\mathrm{C}-\mathrm{N}$ stretching vibrations that can be contributed to the present of amine group. For Amide III, it was found between the spectrum $1237.70-1241.31 \mathrm{~cm}^{-1}$ where the intensity is higher for $\mathrm{G}$ and $\mathrm{G}$ :S plasticizers compared to $\mathrm{S}$ and DI. Such displacement is due to the additional interactions between the glycerol and the film structure as the amount of the free water is higher than others. This was in agreement with the study by Bergo and Sobral (2007) and Nor et al. (2017). For the amide A, based on the FTIR results with wide peaks occurring in the range between $3317.25-3319.93 \mathrm{~cm}^{-1}$ respectively. The displacements were occurred with the increased in intensity and sharper peaks in comparing the control film with the film incorporated with the plasticizers due to the contribution of $-\mathrm{OH}$ group from the plasticizers. The peaks generally correspond to the -NH stretching coupled with hydrogen bond which responsible with the width (Muyonga et al. 2004).

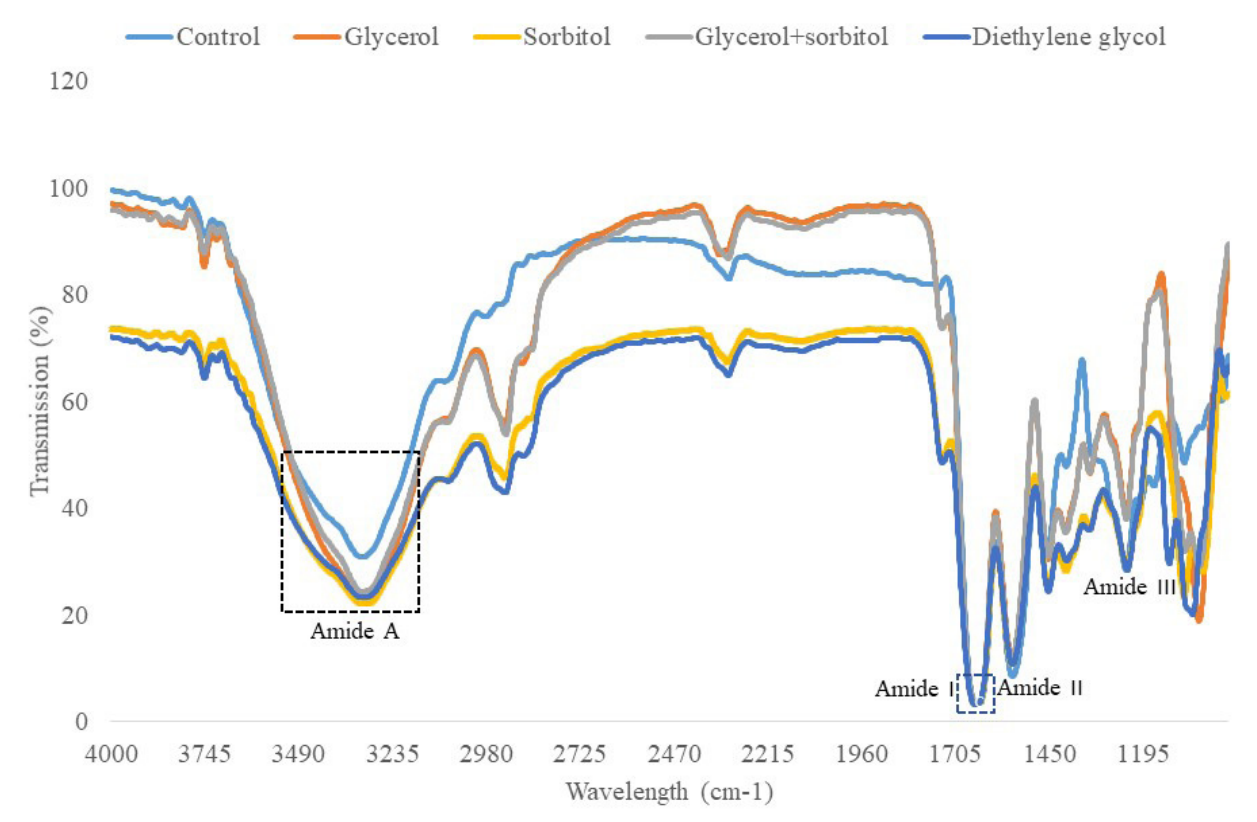

FIGURE 4. TIR spectra of the gelatin based films without plasticizer, control and incorporated with $30 \%$ of different plasticizers: Diethylene glycol, Glycerol, Glycrol:sorbitol and Sorbitol 
Generally, the results manifested that all the films showed absorption peaks in the same regions, irrespective of plasticizer type which shows that they possess similar functional groups. Though the plasticizer types were different, there are all classified as polyols. Additionally, the presence of aliphatic of alcohol in the plasticized film were shown indicating due to the availability of the plasticizer.

\section{CONCLUSION}

The different plasticizers incorporation into the gelatin films showed significant effects towards the functionalities of the Tilapia's fish scale gelatin film. For the thermal degradation of the plasticized gelatin films occurred in three different stages which are evaporation or dehydration of the loosely bound water and low molecular weight compound in the films (less than 150 $\left.{ }^{\circ} \mathrm{C}\right)$; evaporation of plasticizer compounds $\left(270-310^{\circ} \mathrm{C}\right)$; decomposition and depolymerization of gelatin film (more than $310^{\circ} \mathrm{C}$ ). Interestingly, GS-plasticized film enhances the tensile strength and reduce the brittleness of glycerol and sorbitol plasticized film. Hence, better tensile properties with acceptable thermal stability was achieved by combining the glycerol and sorbitol. In summary, the addition of plasticizers with different hygrocopicities was accompanied by impacting in glass transition temperature, thermal degradation, chemical interaction between protein-protein and plasticizerprotein and strength with flexibility of the Tilapia's fish scale gelatin films.

\section{ACKNOWLEDGEMENTS}

This work was supported by the Putra grant IPS/2017/9547500 and Putra grant 2017/9547000.

\section{REFERENCES}

ASTM 2002. Standard test method for tensile properties of thin plastic sheeting: Method D882-02. In Annual Book of ASTM Standards. Philadephia: American Society for Testing and Materials.

Backfolk, K., Holmes, R., Ihalainen, P., Sirviö, P., Triantafillopoulos, N. \& Peltonen, J. 2007. Determination of the glass transition temperature of latex films: Comparison of various methods. Polymer Testing 26(8): 1031-1040.

Bergo, P. \& Sobral, P.J.A. 2007. Effects of plasticizer on physical properties of pigskin gelatin films. Food Hydrocolloids 21(8): 1285-1289.

Chang, P.R., Jian, R., Yu, J. \& Ma, X. 2010. Fabrication and characterisation of chitosan nanoparticles/plasticised-starch composites. Food Chemistry 120(3): 736-740.

Chuaynukul, K., Nagarajan, M., Prodpran, T., Benjakul, S. \& Prasarpran, S. 2017. Impacts of plasticizer and pre-heating conditions on properties of bovine and fish gelatin films fabricated by thermo-compression molding technique. Italian Journal of Food Science 29(3): 487-504.
González, P., Medina, C., Famá, L. \& Goyanes, S. 2016. Biodegradable and non-retrogradable eco-films based on starch-glycerol with citric acid as crosslinking agent. Carbohydrate Polymers 138: 66-74.

Hoque, M.S., Benjakul, S. \& Prodpran, T. 2011. Effects of partial hydrolysis and plasticizer content on the properties of film from cuttlefish (Sepia pharaonis) skin gelatin. Food Hydrocolloids 25(1): 82-90.

Jongjareonrak, A., Benjakul, S., Visessanguan, W., Prodpran, T. \& Tanaka, M. 2006. Characterization of edible films from skin gelatin of brownstripe red snapper and bigeye snapper. Food Hydrocolloids 20(4): 4920-501.

Limpan, N., Prodpran, T., Benjakul, S. \& Prasarpran, S. 2010. Properties of biodegradable blend films based on fish myofibrillar protein and polyvinyl alcohol as influenced by blend composition and $\mathrm{pH}$ level. Journal of Food Engineering 100(1): 85-92.

Limpisophon, K., Tanaka, M., Weng, W.Y., Abe, S. \& Osako, K. 2009. Characterization of gelatin films prepared from under-utilized blue shark (Prionace glauca) skin. Food Hydrocolloids 23(7): 1993-2000.

Mohammad, A.W., Kumar, A.G. \& Basha, R.K. 2014. Optimization of enzymatic hydrolysis of tilapia (Oreochromis spp.) scale gelatine. International Aquatic Research 7(1): 27-39.

Muyonga, J.H., Cole, C.G.B. \& Duodu, K.G. 2004. Characterisation of acid soluble collagen from skins of young and adult Nile perch (Lates niloticus). Food Chemistry 85(1): 81-89.

Nor, M.H.M., Nazmi, N.N.M. \& Sarbon, N.M. 2017. Effects of plasticizer concentrations on functional properties of chicken skin gelatin films. International Food Research Journal 24(5): 1910-1918.

Nur Hanani, Z.A., Roos, Y.H. \& Kerry, J.P. 2014. Use and application of gelatin as potential biodegradable packaging materials for food products. International Journal of Biological Macromolecules 71: 94-102.

Saikia, J.P., Banerjee, S., Konwar, B.K. \& Kumar, A. 2010. Biocompatible novel starch/ polyaniline composites: Characterization, anti-cytotoxicity and antioxidant activity. Colloids and Surfaces B: Biointerfaces 81(1): 158-164.

Sanyang, M.L., Sapuan, S.M., Jawaid, M., Ishak, M.R. \& Sahari, J. 2016. Effect of plasticizer type and concentration on physical properties of biodegradable films based on sugar palm (Arenga pinnata) starch for food packaging. Journal of Food Science and Technology 53(1): 326-336.

Sanyang, Muhammed L., Sapuan, S.M., Jawaid, M., Ishak, M.R. \& Sahari, J. 2015. Effect of plasticizer type and concentration on tensile, thermal and barrier properties of biodegradable films based on sugar palm (Arenga pinnata) starch. Polymers 7(6): 1106-1124.

Shaw, N.B., Monahan, F.J., O'Riordan, E.D. \& O'Sullivan, M. 2002. Physical properties of WPI films plasticized with glycerol, xylitol, or sorbitol. Journal of Food Science 67(1): 164-167.

Siew, D.C.W., Heilmann, C., Easteal, A.J. \& Cooney, R.P. 1999. Solution and film properties of sodium caseinate/glycerol and sodium caseinate/polyethylene glycol edible coating 
systems. Journal of Agricultural and Food Chemistry 47(8): 3432-3440.

Thomazine, M., Carvalho, R. \& Sobral, P. 2005. Properties physical properties of gelatin films plasticized by blends of glycerol and sorbitol results and discussion. Food Engineering and Physical Properties 70(3): 172-176.

Tongnuanchan, P., Benjakul, S. \& Prodpran, T. 2014. Structural, morphological and thermal behaviour characterisations of fish gelatin film incorporated with basil and citronella essential oils as affected by surfactants. Food Hydrocolloids 41: 33-43.

Tongnuanchan, P., Benjakul, S. \& Prodpran, T. 2013. Physicochemical properties, morphology and antioxidant activity of film from fish skin gelatin incorporated with root essential oils. Journal of Food Engineering 117(3): 350-360.

Tongnuanchan, P., Benjakul, S. \& Prodpran, T. 2012. Properties and antioxidant activity of fish skin gelatin film incorporated with citrus essential oils. Food Chemistry 134(3): 1571-1579.

Weng, W. \& Wu, F. 2015. Water resistance and mechanical property improvement of tilapia (Tilapia zillii) scale gelatin films by dehydrated thermal treatment. Journal of Food Science and Technology 52(6): 3358-3366.

Weng, W., Zheng, H. \& Su, W. 2014. Characterization of edible films based on tilapia (Tilapia zillii) scale gelatin with different extraction pH. Food Hydrocolloids 41: 19-26.

Xu, Y.X., Kim, K.M., Hanna, M.A. \& Nag, D. 2005. Chitosanstarch composite film: Preparation and characterization. Industrial Crops and Products 21(2): 185-192.
Yang, L. \& Paulson, A.T. 2000. Mechanical and water vapour barrier properties of edible gellan films. Food Research International 33(7): 563-570.

Yi, J.B., Kim, Y.T., Bae, H.J., Whiteside, W.S. \& Park, H.J. 2006. Influence of transglutaminase-induced cross-linking on properties of fish gelatin films. Journal of Food Science 71(9): E376-E383.

Nazatul Shima Azmi, Roseliza Kadir Basha*, Nurfatin Nabila Tajul Arifin, Siti Hajar Othman \& Mohd Afandi P. Mohammed Department of Process and Food Engineering

Faculty of Engineering

Universiti Putra Malaysia

43400 UPM Serdang, Selangor Darul Ehsan

Malaysia

Nazatul Shima Azmi

Department of Mechanical Engineering Technology

Faculty of Engineering Technology

University Tun Hussein Onn Malaysia

84600 Pagoh, Johor Darul Takzim

Malaysia

*Corresponding author; email: roseliza@upm.edu.my

Received: 15 October 2019

Accepted: 8 May 2020 